\title{
The costs of icebreaking services: an estimation based on Swedish data
}

\author{
Eva Lindborg ${ }^{1} \cdot$ Peter Andersson $^{2}$ (D)
}

Received: 13 December 2018 / Accepted: 9 December 2019 / Published online: 8 January 2020

(C) The Author(s) 2020

\begin{abstract}
In winter, the sea around Sweden and Finland as well as parts of the waters around Canada, Russia and the USA become ice covered, and ships may require assistance from icebreakers to proceed to their destinations. This paper accordingly analyses the cost structure and estimates the cost of icebreaking operations at sea, including the costs of external effects of the icebreakers' emissions, and analyses the consequences of different pricing schemes for financing icebreaking services. A regression analysis was carried out based on data from icebreaking services in Sweden over 14 winters from 2001/2002 to $2015 / 2016$. The social marginal cost of an average assistance operation (which may involve more than one ship) is estimated at EUR 6476 and for each assisted ship EUR 5304. The same cost is EUR 907 per running hour for the icebreakers and EUR 1990 per hour a ship is assisted. Each additional nautical mile sailed by an icebreaker costs society EUR 141 and each assisted nautical mile EUR 234. The marginal cost is found not to be related to winter severity. Despite the significant social marginal costs, not including large fixed costs, icebreaking in Sweden and Finland is free of charge. The advantages and disadvantages of four pricing models that can be applied to cover at least parts of the costs to society are discussed. All models could create new distortions, but a price per assisted hour may be worth applying in practice.
\end{abstract}

Keywords Icebreaking services $\cdot$ Transportation costs $\cdot$ Social marginal cost $\cdot$ Maritime costs $\cdot$ Financing

\section{Introduction}

In winter, waters become ice covered, for example, in the Baltic Sea (see, e.g. Fig. 1) and along parts of the coasts and rivers and in many lakes in Canada, Russia and the

Peter Andersson

peter.andersson@liu.se

1 Traffic Analysis, Torsgatan 30, SE-113 21 Stockholm, Sweden

2 Department of Economics, Linköping University, SE-581 00 Linköping, Sweden 
a

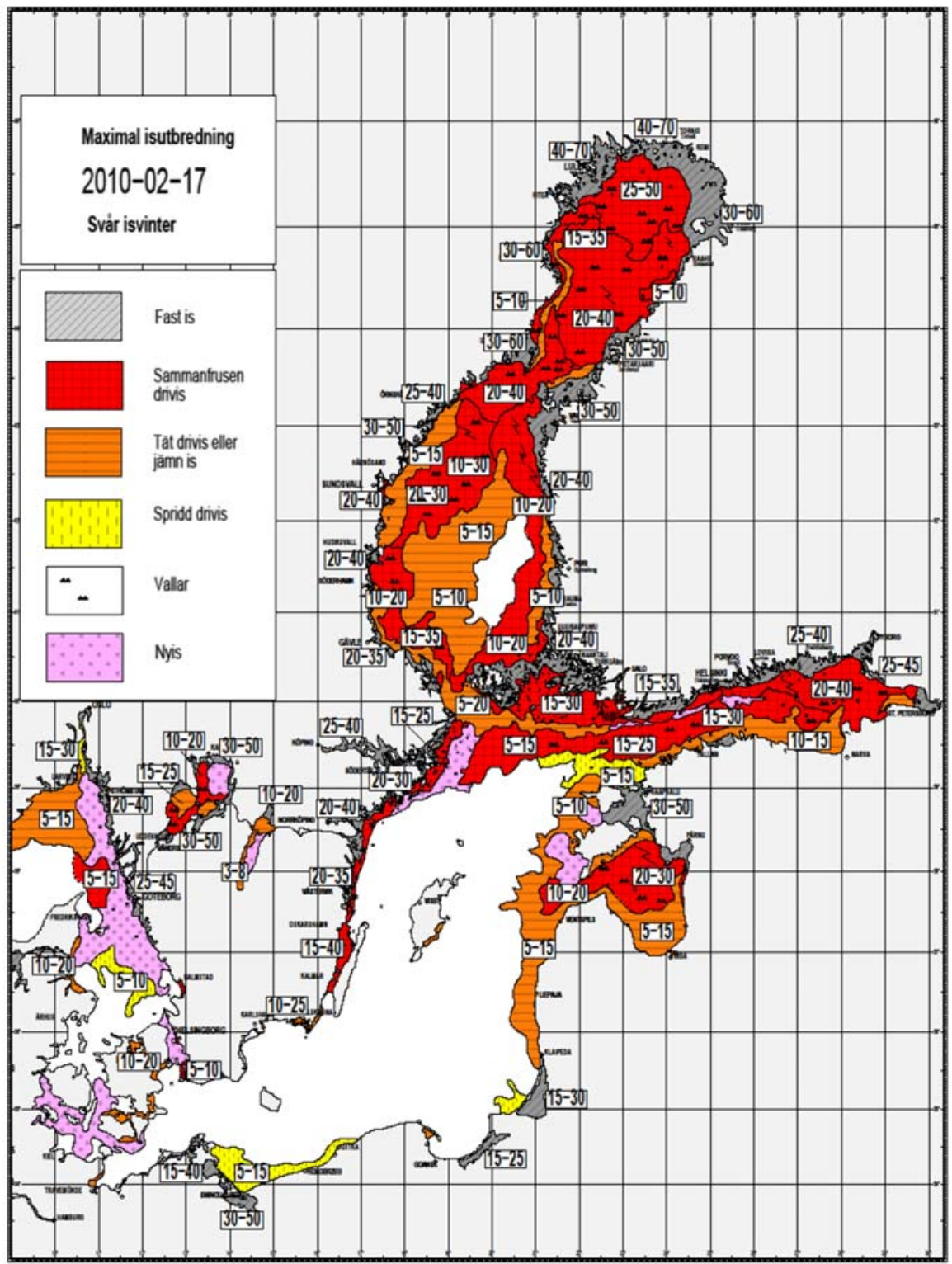

Fig. 1 a The maximum ice extent during the severe winter of 2009/2010. b The maximum ice extent during the mild winter of 2014/2015. Source: Swedish Meteorological and Hydrological Institute (2017)

USA. In such conditions, ships may require assistance from icebreakers to proceed to their destinations. The northern coasts of Sweden and Finland always become ice covered, and during cold winters, most of the waters surrounding ports in Sweden, Finland, Russia and Estonia in the Baltic Sea freeze over.

Little is known about the cost structure of icebreaking services, despite the relatively high annual costs of providing them. The Swedish Maritime Administration is responsible for icebreaking at sea in Sweden, and its icebreaking service is free of charge. 
b

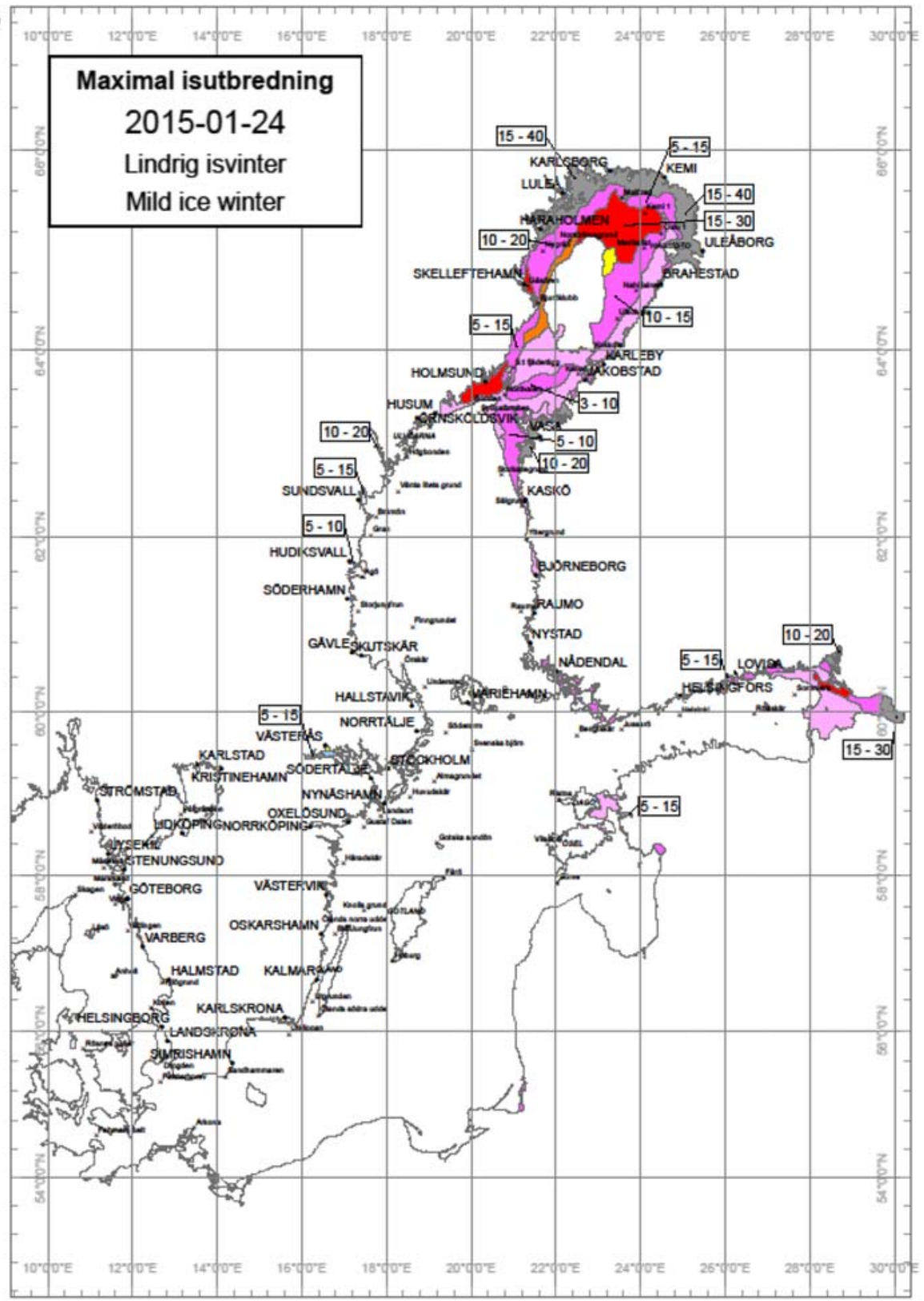

Fig. 1 (continued)

During the 2012-2017 period, the Swedish Maritime Administration incurred an annual costs of EUR 29-40 million to provide icebreaking. This figure can be compared with the total annual cost of pilotage services of EUR 61 million and of fairway and lighthouse maintenance of EUR 30 million (Swedish Maritime 
Administration Annual Report 2017). In Finland, the Finnish Transport Agency is responsible for icebreaking services at sea, currently by tendering nine icebreakers from the state-owned company Arctica, and as in Sweden, icebreaking is free of charge. The total annual cost of icebreaking in Finland was EUR 35-59 million from 2012 to 2017. The cost of icebreaking in Finland is of at least the same magnitude as that of pilotage services, which totalled around EUR 35 million in 2016 (VTI 2018).

For the countries concerned, icebreaking services are crucial to the shipping industry and to the industries and consumers in the regions surrounded by ice in winter. Providing these services incurs significant costs. Nevertheless, except for engineering aspects, research into icebreaking has so far not considered its economics. Instead, research has targeted, for example, the impact of climate change and opening the Arctic route (e.g. Somanathan et al. 2007; Parsons et al. 2011; Gritsenko and Kiiski 2015; Dalaklis et al. 2018) and operational safety (Boström and Österman 2017), whereas optimal pricing research has focussed on fairways or ports (e.g. Coase 1974; Haralambides et al. 2001; Meersman et al. 2010), while further economic analysis has been limited to the cost-benefit analysis of icebreaker improvements (Lyridis et al. 2005). Knowledge of the cost structure of icebreaking is insufficient in maritime economics. Such knowledge would constitute an important basis for investment decisions, organisational concerns, efficient pricing and financing design of the services and analysis of the effects of providing them for free.

This paper accordingly analyses the cost structure of icebreaking services at sea, including the costs of their external effects (i.e. icebreaker emissions) and the consequences of different pricing schemes for financing the services and promoting efficiency. The estimated costs are based on data on icebreaking in Sweden over 14 winters from $2001 / 2002$ to $2015 / 2016$.

\section{Icebreaking services in Sweden}

According to the political agenda in Sweden, social marginal cost should be considered in policy and management in the transportation sector. ${ }^{1}$ This concept includes the total costs to society resulting from service production, i.e. both the costs of the resources used by the producer and the external costs to the rest of society, for example, for emissions, accidents and congestion. The Swedish governmental agency Transport Analysis is commissioned by the government to report annually on the social marginal costs of the transport sector in relation to the imposition of taxes and other charges in various parts of the Swedish and European transport sector. ${ }^{2}$ The Swedish government has also commissioned the Swedish National Road and Transport Research Institute (VTI) to conduct research into the social marginal costs of transport, with a recent focus on air and sea transport. ${ }^{3}$ A study of icebreaking costs has been published by Transport Analysis (2017).

Icebreaking services in Sweden over the open sea and into sheltered waters are provided by the Swedish Maritime Administration, whereas the ports are responsible

\footnotetext{
${ }^{1}$ Government Bill 2005/06:160.

${ }^{2}$ Ordinance 2010:186 with instruction for Traffic Analysis.

${ }^{3}$ Government Decision 2017-02-09. NT2017/01023/TS.
} 
for icebreaking through the archipelagos to designated berths using their icebreaking tugboats. Shipping companies pay no fees for the icebreaking assistance from the Maritime Administration. As the maritime operators do not have to consider the costs of icebreaking when sailing to ports surrounded by ice, the cost of icebreaking services can be regarded as an external cost for them. An external transport cost is generally not borne by the transport users and therefore is not taken into account when they make transport decisions (Korzhenevych et al. 2014). Instead, the fairway fees paid by ships destined to all Swedish ports all year round are to cover the total costs to the Swedish Maritime Administration of icebreaking in winter. ${ }^{4}$ The costs to society of emissions from icebreakers are not internalised by fees or taxes, unlike, for example, emissions from cars and trucks.

The extent of the ice-covered sea and thus the need for icebreaking vary substantially from year to year. The Swedish Meteorological and Hydrological Institute defines different kinds of winters, considering the maximum extent of the ice in square kilometres during the season. Based on that definition, the Swedish Maritime Administration classifies the icebreaking season as one of four types: very mild, mild, normal and severe. The prime criterion is the maximum extent of the ice, but the length of the ice period and the effects of wind and currents on the possibility of sailing are also considered (Swedish Maritime Administration 2019b). In a very mild winter, as in $2014 / 2015$, a total of 320 ships were assisted by state icebreakers, whereas in a severe winter, as in 2009/2010, 3720 ships were assisted. It is not only the ice extent that determines the severity. On the open sea, the wind moves the ice, which can cause rafted, ridged or brash ice barriers that are much more difficult to pass through than is level sea ice. In mild winters when only parts of the Bay of Bothnia are covered with ice, the wind can move the ice from one coast to the other and create ridges bigger than those created under more stable conditions. Figure 1a, b shows the maximum extent of ice during two winters with contrasting conditions. Figure 1a is from the severe winter of 2009/2010, when the entire Bay of Bothnia and most of the northern Baltic Sea and the sea west of Scandinavia was ice covered. Figure $1 \mathrm{~b}$ is from the mild winter of $2015 / 2016$, when only the northernmost part of the coast was ice covered.

Icebreakers assist the ships by creating an open channel in the ice, moving in front of the ship/s, or, in severe conditions or with smaller ships, towing them through the ice. Several ships may be assisted together in a convoy, with the ships experiencing the most difficulties moving through the ice being placed nearest the icebreaker. The ice channel that occurs can seldom be reused later by other ships, as the wind soon moves the ice and closes the channel. Convoys are most common during severe winters. The average number of assisted ships per assistance operation has been calculated based on Swedish Maritime Administration data to be 1.45 during severe winters versus 1.051.1 during the other types of winters.

The Swedish Maritime Administration has a goal that the average waiting time for ship assistance should not exceed $4 \mathrm{~h}$, and the capacity of the icebreaking services is designed with reference to this goal. Sweden has had five state icebreakers over the last two decades. They are put into service one by one when the ice spreads at the beginning

\footnotetext{
${ }^{4}$ The fairway fee is based on the number of arrivals per month, net tonnage, the quantity of goods or passengers arriving at the port, and an environmental differentiation based on the Clean Shipping Index (CSI). The fee is reduced after two arrivals in one month (Swedish Maritime Administration 2019a).
} 
of winter and removed from service when conditions improve, and the ice disappears. Extra capacity can be obtained by using other resources, such as fairway service ships belonging to the Swedish Maritime Administration or by hiring local icebreaking tugboats. During the studied period, the Swedish Maritime Administration also had an agreement that, when needed, it could use three offshore vessels normally travelling in the North Sea for icebreaking, the so-called Viking icebreakers.

The icebreaking period normally extends from December to May. The Swedish and Finnish authorities issue ice restrictions for different areas as to the minimum size and ice class of the ships to be offered assistance. Swedish and Finnish authorities coordinate their services, and icebreakers can assist ships heading to both countries when required.

\section{Data and methodology}

In this study, the social marginal costs of icebreaking have been calculated by estimating a cost function using time series data. In addition to costs per assisted ship, this study also analyses costs per assistance operation and in relation to assisted distance and time.

\subsection{Previous estimates in Sweden}

In Sweden, there are a few previous studies of icebreaking costs. They are in the form of case studies or calculations of the average variable cost, which is assumed to equal the social marginal cost. Vierth (2016) estimated the marginal cost of icebreaking by dividing what the study identified as the total variable cost, inclusive of the emission cost, by volume, estimating a marginal cost of EUR 7238 per assistance operation. This includes the cost of fuel, lubricants, and external effects (in the form of icebreaker emissions, as valued by Nerhagen 2016). When the costs of maintenance and hired icebreakers were included, the estimated cost rose to EUR 12985 per assistance operation in that study. Vierth (2016) concluded that the cost of icebreaking is more closely linked to the severity of the winter than to the number of assistance operations. However, this analysis will demonstrate that such maritime operational costs include significant fixed costs and do not support the contention that winter severity affects the marginal cost.

Melin and Creutzer (2014) conducted a case study of assistance to the port of Luleå, finding the marginal cost to be EUR 5405 per assistance operation (at the 2001 price level and exchange rate). Eriksson et al. (2009) presented estimates of the upper limit on variable costs per day for four types of icebreakers. For the largest icebreaker, the cost was EUR 3672 per day, 87\% of this coming from fuel consumption. The Swedish Ministry of Enterprise and Innovation (Näringsdepartementet 2003) calculated the total marginal cost of icebreaking, using an approach similar to that of Vierth, to be EUR 2.1-8.0 million per year.

\subsection{Data}

To estimate a cost function, two approaches are possible. If there are firms or production plants of different size, an estimate based on panel data is possible. Icebreaking 
operations are however carried out by a single operator. Thus, instead, time series analysis has to be made, using data from the single provider for a number of years. Examples of estimating cost functions with regression analysis in the maritime sector are found in Vilmsmeier and Martinez-Zarzoso (2010), Effiong et al. (2016) and Vilmsmeier (2016), Tchang (2019). In this study, annual costs for 14 years were statistically analysed to estimate the marginal cost. The prime source of data was information from the Swedish Maritime Administration about various costs of icebreaking operations, fuel consumption, number of assistance operations and number of assisted ships. Data covering 14 years from winter 2001/2002 to winter 2015/2016 were used. Winter 2010/2011 was omitted from the analysis because the fuel consumption data were misreported, according to communication to the authors from the Swedish Maritime Administration. Maritime operating costs were taken from yearly reports from the Swedish Maritime Administration entitled A summary of the ice season and icebreaking activities (Swedish Maritime Administration 2001, 2002, 2003, 2004, 2005, 2006, 2007, 2008, 2009, 2010, 2011, 2012, 2013, 2014, 2015, 2016).

The total cost to society of icebreaking in a year is:

$$
\mathrm{TC}=\mathrm{FC}_{\mathrm{A}}+\mathrm{FC}_{\mathrm{I}}+\mathrm{VC}_{\mathrm{I}}+E
$$

where.

$\mathrm{FC}_{\mathrm{A}} \quad$ Swedish Maritime Administration administrative costs for icebreaking

$\mathrm{FC}_{\mathrm{I}}$ fixed costs of state icebreakers (i.e. capital and manning costs) and a fixed fee for Viking icebreakers

$\mathrm{VC}_{\mathrm{I}}$ variable costs of icebreakers: "maritime operating costs"

$E \quad$ external costs: emissions from icebreaker operation

During 1 year, both capital and manning costs are fixed. All icebreakers are manned at stand-by levels throughout the ice season regardless of whether they are put into service, as the winter severity is not known in advance. Capital costs are also fixed in the longer run. The Swedish Maritime Administration has had the same fleet of five icebreakers throughout the studied period. In the very long run, capital costs can be flexible, if the Maritime Administration decides to adjust the fleet because of change in the demand for icebreaking services. The demand may change in the long run if more goods are shipped, if more ships are less equipped for sailing in ice or if climate change reduces the need for icebreaking. In this study, capital and manning costs are considered fixed. An "average social marginal cost" of all operations during the studied period is estimated. The actual marginal cost of a specific assistance operation can vary around this average depending on many situationspecific factors, such as the ice condition and characteristics of the assisted ship/s.

The total variable cost to society $\left(\mathrm{TVC}=\mathrm{VC}_{\mathrm{I}}+E\right)$ in this study comprises:

- Maritime operating cost $\left(\mathrm{VC}_{\mathrm{I}}\right)$, consisting of costs for:

- Fuels and lubricants for state icebreakers

- Share of maintenance costs for state icebreakers

- Share of the cost of the Viking icebreakers

- Hired auxiliary icebreakers

- External effects (E), consisting of costs for:

- Air pollution emissions 
- Greenhouse gas emissions

As the cost of fuels and lubricants for state icebreakers is an important operational cost, the entire cost is included in the regression.

The maintenance cost for state icebreakers has been adjusted to include only the share that varies with the annual operations, compared with the original cost data, which covers only the total annual cost of maintaining the icebreakers. According to experts at the Swedish Maritime Administration, on average 10-20\% of the maintenance cost varies with the icebreaking operations. The total cost of maintenance tends to be higher when the winter is mild, since fewer assistance operations make the icebreakers more available for maintenance work. To adjust the data, first, the average total maintenance cost per assisted ship is calculated, using data from all years. Second, the average number of assisted ships for very mild, mild, normal and severe winters is calculated. Then, the average maintenance cost per year for very mild, mild, normal and severe winters is calculated by multiplying the average total maintenance cost per assisted ship by the average number of assisted ships for very mild, mild, normal and severe winters, respectively. Finally, the average variable maintenance cost is estimated by multiplying the total cost by 0.15 for every type of winter. In the adjusted data, all winters defined as very mild have the same variable maintenance cost, and all winters defined as mild, normal or severe have the average variable maintenance cost for a mild, normal or severe winter.

The Swedish Maritime Administration has had a special agreement whereby it pays a yearly fixed fee and in return can use the three so-called Viking icebreakers, normally used in offshore operations in the North Sea. When a Viking icebreaker was used for icebreaking operations, the Swedish Maritime Administration also paid a fee for running costs. In the available data, the fee for the Viking icebreakers is shown as a lump sum per year, meaning that it is impossible to separate the fixed fee from the fee associated with the running cost. During the studied period, the Viking icebreakers were used in four winter seasons. To approximate the running cost for the years when the Viking icebreakers were used, the cost from the closest previous year when the Viking icebreakers were not hired was deducted from the total cost of the Viking icebreakers for the year of use. In addition to the Viking icebreakers, the Swedish Maritime Administration hires auxiliary local icebreaking tugboats. The total cost of the auxiliary icebreakers is available in the dataset and used in the analysis. It is assumed that the opportunity cost for all hired Viking and auxiliary icebreakers is represented in the payment for using them.

The costs of icebreaking operations reported by the Maritime Administration also include so-called local icebreaking operations, which are not directly related to assisting a particular ship but rather to preventing ice from getting stuck, for example, under bridges in ports or in channels. Such local icebreaking was carried out every year in the dataset except one, but the cost of local icebreaking is known for only 5 years. A separate linear regression was conducted to determine the cost of local icebreaking using the share of local icebreaking relative to total operations. The result is that the total variable cost to society (TVC) for each year used in the regressions has been reduced by $0.5-11 \%$ of the cost, depending on the share of the local icebreaking each year. 
Table $1 \quad \mathrm{VC}_{\mathrm{I}}$ Maritime operating costs per year

\begin{tabular}{|c|c|c|c|c|}
\hline & $\begin{array}{l}\text { Average } \\
\text { cost }\end{array}$ & $\begin{array}{l}\text { Min cost season } \\
2003 / 2004\end{array}$ & $\begin{array}{l}\text { Max cost season } \\
2010 / 2011\end{array}$ & $\begin{array}{l}\text { Standard } \\
\text { deviation }\end{array}$ \\
\hline Cost of fuel and lubricants & $3,954,261$ & $1,607,536$ & $4,269,181$ & $1,730,730$ \\
\hline $\begin{array}{l}\text { Average maintenance costs depending on the } \\
\text { type of winter } * \beta, \beta=0.15\end{array}$ & $1,107,192$ & 286,515 & $3,944,325$ & $1,070,032$ \\
\hline $\begin{array}{l}\text { Opportunity cost for Viking icebreakers, } \\
\text { variable fee for years deployed is used }\end{array}$ & 693,821 & - & $5,711,456$ & $1,554,097$ \\
\hline Opportunity cost for hired auxiliary icebreakers & 601,441 & 380,902 & $1,743,794$ & 470,126 \\
\hline $\mathrm{VC}_{\mathrm{I}}$ maritime operating costs & $6,356,715$ & $2,274,952$ & $15,668,756$ & $3,526,896$ \\
\hline
\end{tabular}

Thus,

$$
V C_{1}(1-\gamma)=\left(F_{1}+\beta M_{1}+V+H\right) *(1-\gamma)
$$

where

$\begin{array}{ll}\mathrm{VC}_{\mathrm{I}}(1-\gamma) & \begin{array}{l}\text { maritime operating costs exclusive of local icebreaking } \\ \text { cost of fuel and lubricants }\end{array} \\ M & \begin{array}{l}\text { average maintenance costs depending on the type of winter } \\ \text { share related to icebreaking operations, } 0.15 \text { is used }\end{array} \\ \beta & \begin{array}{l}\text { opportunity cost for Viking icebreakers, variable fee for } \\ V\end{array} \\ & \begin{array}{l}\text { years deployed is used } \\ \text { opportunity cost for hired auxiliary icebreakers, yearly payment is used }\end{array} \\ \gamma & \text { the share of local icebreaking }\end{array}$

Table 1 presents a summary of the variable maritime operating costs. The costs of maintenance, Viking icebreakers and hired auxiliary icebreakers are discounted by an index of transport services (SCB 2016b). The cost of fuel and lubricants has been discounted to 2015 price levels using an index of Swedish import prices of crude oil (SCB 2016a). The cost of the 2015/2016 winter season is in current prices. The average exchange rate of 0.107 EUR/SEK for 2015 (Swedish Riksbank 2017) is used throughout the paper to convert amounts originally given in SEK.

To calculate the external cost of the icebreaking operations, data on fuel consumption and emission factors from the Swedish Maritime Administration have been used. According to the emission factors, one cubic meter of fuel used by state icebreakers emits $2660 \mathrm{~kg}$ of carbon dioxide. $\mathrm{CO}_{2}$ emissions are valued according to the Swedish Transport Administration ASEK Guidelines ${ }^{5}$ (2016), at a price of EUR 0.12 per kg of $\mathrm{CO}_{2}$ at the 2014 price level and discounted to the 2015 price level according to the principles in the Guidelines. Air pollution has been valued according to Nerhagen (2016). These values are based on the cost of the impact on human health of secondary particles from nitrogen oxide. Nerhagen presents different costs depending on the geographical area of the emissions. Emissions in northern Sweden are valued at EUR

\footnotetext{
${ }^{5}$ The Swedish Transport Administration issues guidelines for valuing the costs of all modes of transportation, to make calculations of social marginal costs as correct as possible. This includes the valuation of external effects and is based on the latest research.
} 
38 per tonne of fuel, the value used here, as most icebreaking operations occur in this area.

Information about fuel consumption is available only for the state icebreakers. $A$ summary of the ice season and icebreaking activities (Swedish Maritime Administration 2001, 2002, 2003, 2004, 2005, 2006, 2007, 2008, 2009, 2010, 2011, $2012,2013,2014,2015,2016)$ provides the names of the hired icebreakers. This information has been combined with the data on engine power from the Swedish ships' register (Swedish Transport Agency 2015). Information was not found for all hired auxiliary icebreakers, but for the identified ones, the average engine power was $9 \%$ of that of the state icebreakers. The engine power of the Viking icebreakers was on average $88 \%$ of that of the state icebreakers. Assuming fuel consumption to be linearly related to engine power, the fuel consumption is set to $88 \%$ of that of the state icebreakers for the Viking icebreakers and $9 \%$ for the hired auxiliary icebreakers.

Effects on the environment other than emissions are assumed to be insignificant. However, there may be external effects on other ships as well. Assisting one ship may have both positive and negative effects on other ships in the area. Positive effects occur when other ships can join the first one assisted in a convoy, or occasionally when the ice channel remains open and can be used again. On the other hand, there may be congestion and waiting times for ships if all icebreakers are occupied. These effects work in opposite directions and it was impossible to estimate the magnitude of either one, so such external effects on other ships are excluded from the analysis.

Figure 2 shows maritime operating costs $\left(\mathrm{VC}_{\mathrm{I}}(1-\gamma)\right)$ and the total variable cost to society $\left(\mathrm{TVC}(1-\gamma)=\mathrm{VC}_{\mathrm{I}}(1-\gamma)+\mathrm{E}(1-\gamma)\right)$ relative to the number of assisted ships for each of the 14 studied years. The average number of assisted ships during the studied period is 1181 per year.

Data on running hours, assisted hours, nautical miles and assisted nautical miles for each winter season were provided to the authors by the Swedish Maritime Administration. The data on operation running hours, assisted hours, nautical miles and assisted nautical miles cover both the state icebreakers and the Viking icebreakers and are not separated by type of icebreaker. Separate information for state icebreakers, Viking

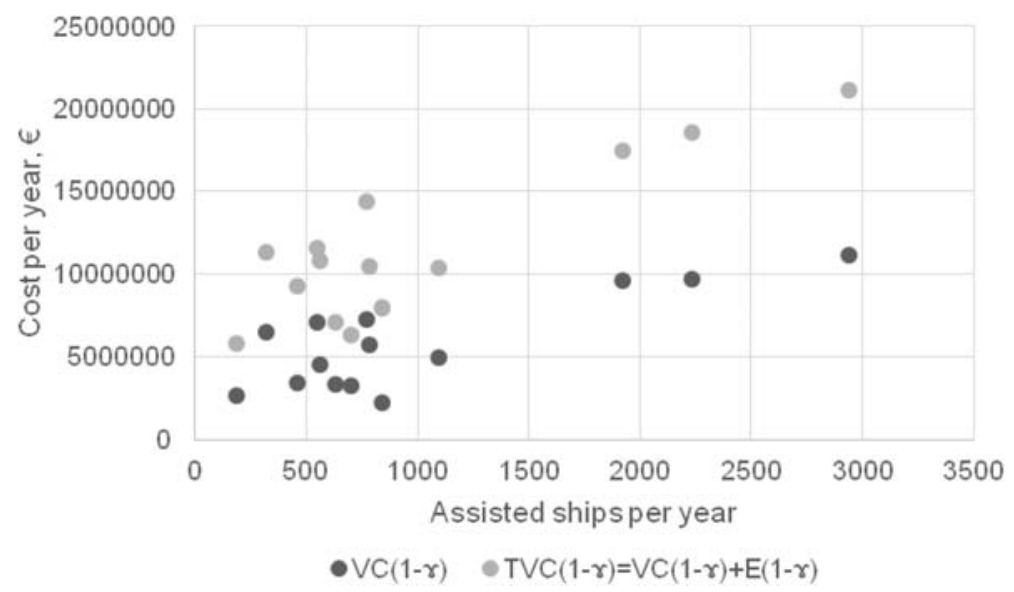

Fig. 2 Maritime operating costs (VC) and total variable cost to society (TVC) in EUR relative to the number of assisted ships 
icebreakers and hired auxiliary icebreakers with regard to the numbers of assistance operations and assisted ships is available for each year in A summary of the ice season and icebreaking activities.

\section{Methodology}

An ordinary least square regression analysis with a linear model ( $3 a$ a) was conducted to estimate the social marginal cost (b) explained by the amount of icebreaking.

$$
\operatorname{TVC}(1-\gamma)(q)=a+b^{*} q_{i}+e
$$

In expression (3a), $a$ is a fixed cost for icebreaking, $b$ the social marginal cost (SMC) of icebreaking, $q_{i}$ the amount of icebreaking, measured alternatively as the total number of assistance operations or the total number of assisted ships and $e$ is an error term.

The costs for icebreaking in terms of running hours, assisted hours, nautical miles and assisted nautical miles were analysed by taking the sum of the operational and external costs of state and Viking ice breakers. This corresponds to model (3b), in which $s$ indicates state icebreakers and $v$ Viking icebreakers. In model (3b), $q$ therefore represents the amount of icebreaking, measured alternatively as the total number of assistance operations, assisted ships, running hours, assisted hours, nautical miles, or assisted nautical miles.

$$
\operatorname{TVC}_{\mathrm{s}+\mathrm{v}}(1-\mathrm{v})\left(\mathrm{q}_{\mathrm{s}+\mathrm{v}}\right)=a_{\mathrm{s}+\mathrm{v}}+b_{\mathrm{s}+\mathrm{v}} * \mathrm{q}_{\mathrm{s}+\mathrm{v}}+e
$$

\section{Results}

Models (3a) and (3b) have high explanatory power and a statistically significant social marginal cost regardless of whether the cost is defined in terms of assistance operations, assisted ships, running hours, assisted hours, nautical miles or assisted nautical miles ${ }^{6}$ (see Table 2).

The first two rows show the costs for all icebreakers, including the hired auxiliary ones. Significant marginal costs are related to icebreaking operations. The marginal cost per assistance operation is higher than the cost per assisted ship, which can be explained by the assistance operations involving more than one icebreaker. The following four rows exclude the auxiliary icebreakers because of lack of data. The difference between running hour and assisted hour and between nautical mile and assisted nautical mile is explained by the fact that the icebreakers do not assist ships all the time: they may be underway to another location for the next assistance operation, undergoing a fortnightly change of crew or lying stand-by in the ice awaiting the next mission.

Another notable finding is that parameter $a$ is significantly different from zero, implying that operational and external costs also include a fixed cost component. This finding clearly shows that the average variable cost is not a representative measure of

\footnotetext{
$\overline{{ }^{6} \text { Numbers marked with } * * * \text { and }} * *$ are significant at the $0.1 \%$ and $1 \%$ levels, respectively.
} 
Table 2 Estimated fixed cost (a) and estimated social marginal cost (b) of icebreaking

\begin{tabular}{llll} 
TVC $(1-\gamma)(q)=a+q \mathrm{i} * b+e$ & $\mathrm{a}$ (EUR millions) & $\mathrm{b}$ (EUR) & $\begin{array}{l}\text { Model's explanatory } \\
\text { power } \\
\text { (adjusted } R^{2} \text { value) }\end{array}$ \\
\hline Assistance (all icebreakers) & & $6476^{* * *}$ & 0.66 \\
Assisted ship (all icebreakers) & $6.0^{* *}$ & $5304^{* * *}$ & 0.74 \\
Running hours (state and Viking icebreakers) & $6.1^{* * *}$ & $907 * *$ & 0.58 \\
Assisted hours (state and Viking icebreakers) & $4.6^{* *}$ & $199^{* * * *}$ & 0.66 \\
Nautical miles (state and Viking icebreakers) & $3.3^{* *}$ & $141^{* * *}$ & 0.74 \\
Assisted nautical miles (state and Viking icebreakers) & $4.4^{* *}$ & $234^{* * * *}$ & 0.65 \\
\hline
\end{tabular}

marginal cost. A separate regression concerning the cost components shows that this fixed cost largely comes from the cost of fuel and lubricants and the external cost, which in turn depend on the fuel consumption.

\section{Sensitivity analysis}

\subsection{Alternative value of air pollution}

An alternative to the emission values presented in Nerhagen (2016) is to use the values found in the Swedish Transport Administration ASEK Guidelines (2016). The ASEK values are based on the cost of reducing pollution (originating from land-based traffic) and are supposed to include regional effects on both human health and nature. The unit values in ASEK are EUR 9.2 per $\mathrm{kg}$ of NOx emissions, EUR 4.6 per $\mathrm{kg}$ of VOC emissions and EUR 3.1 per $\mathrm{kg}$ of $\mathrm{SO}_{2}$ emissions. If the ASEK air pollution values are used, both the fixed (a) and social marginal (b) costs are around 60\% higher than if the Nerhagen values are used (Table 3).

Table 3 Estimated fixed cost (a) and estimated social marginal cost (b) of icebreaking, air pollution valued using Swedish Transport Administration ASEK Guidelines (2016)

\begin{tabular}{|c|c|c|c|}
\hline $\operatorname{TVC}(1-\gamma)(q)=a+q \mathrm{i} * b+e$ & a (EUR millions) & b (EUR) & $\begin{array}{l}\text { Model's explanatory } \\
\text { power (adjusted } \\
R^{2} \text { value) }\end{array}$ \\
\hline Assistance (all icebreakers) & $8.8 * * *$ & $9440 * * *$ & 0.69 \\
\hline Assisted ship (all icebreakers) & $9.5 * * *$ & $7449 * * *$ & 0.77 \\
\hline Running hours (state and Viking icebreakers) & $7.4 * *$ & $1463 * *$ & 0.62 \\
\hline Assisted hours (state and Viking icebreakers) & $7.4 * * *$ & $3234 * * *$ & 0.72 \\
\hline Nautical miles (state and Viking icebreakers) & $5.8 * *$ & $223 * * *$ & 0.77 \\
\hline Assisted nautical miles (state and Viking icebreakers) & $7.2 * *$ & $374 * * *$ & 0.68 \\
\hline
\end{tabular}




\subsection{Does winter severity affect costs?}

To investigate whether winter severity affects the social marginal cost of ice breaking, a dummy analysis was conducted according to the following models:

$$
\begin{aligned}
& \operatorname{TVC}(1-\gamma)(q)=a+d_{a \text { mild }} * \text { dummy }_{\text {mild }}+d_{a \text { very mild }} * \text { dummy }_{\text {very mild }}+b^{*} * q_{i}+d_{b \text { mild }} * \text { dummy }_{\text {mild }} * q_{i}+ \\
& d_{b \text { very mild }} * \text { dummy } y_{\text {very mild }} * q_{i}+e \\
& \operatorname{TVC}(1-\gamma)(q)=a+b * q_{i}+d_{b \text { mild }} * \text { dummy }_{\text {mild }} * q_{i}+d_{b \text { very mild }} * \text { dummy }_{\text {very mild }} * q_{i}+e
\end{aligned}
$$

The dataset includes four very mild, five mild, four normal and one severe winter seasons. In this analysis, the normal and severe winter seasons were included in the

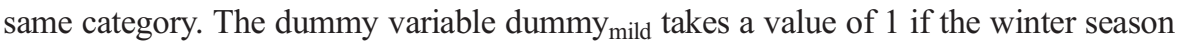

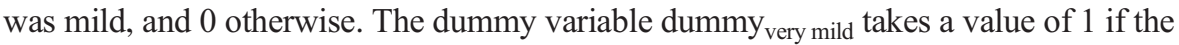
winter season was very mild, and 0 otherwise.

The dummy variables in model (4a) are not significant for either the social marginal cost $\left(d_{\mathrm{b}}\right)$ or the fixed cost $\left(d_{\mathrm{a}}\right)$, indicating that the social marginal cost of icebreaking is not dependent on the winter conditions. However, if the dummy variables are used only for the social marginal cost, as in model (4b), the dummy variable $d_{\mathrm{b} \text { very mild }}$ is significant at the 10 or $5 \%$ level when running hours and assisted hours are used as explanatory variables and at the $5 \%$ level when nautical miles is used as the explanatory variable. The significant dummy variables indicate that the social marginal cost of icebreaking is higher in very mild winters. This may initially appear paradoxical, but very mild winter conditions do not necessarily mean easy ice conditions. In such winters, the ice may fall apart, drift and form walls, so even though there are fewer assisted ships, each assistance operation may be more complicated, increasing the marginal cost. However, overly strong conclusions should not be drawn, because the dataset is rather small.

\subsection{Alternative model specifications}

Some alternative model specifications were also tested. In model (5), separate linear regression analyses were conducted for the operating cost $\left(\mathrm{VC}_{\mathrm{I}}\right)$ and external cost $(E)$, and then the sum of the derivatives of the functions was used to calculate the social marginal cost (SMC).

$$
\operatorname{SMC}(q)=\operatorname{VC}_{1}(1-\gamma)^{\prime}(q)+E(1-\gamma)^{\prime}(q)
$$

The results of models (3) and (5) are rather similar. Model (5) gives a 5-11\% higher social marginal cost when the explanatory variable is assistance operations, assisted ships, running hours, or assisted hours. When the explanatory variable is nautical miles or assisted nautical miles, model (5) gives a 10-23\% lower social marginal cost.

Regression analyses in which both $q$ and $q^{2}$ were used as explanatory variables were also tested, as in model (6), but this model was rejected since the parameters did not result in significant values.

$$
\operatorname{TVC}(1-\gamma)(q)=a+b^{*} q_{i}+c^{*} q_{i}^{2}+e
$$




\section{Conclusion and discussion}

\subsection{Summary}

This study shows that there is a substantial marginal cost to society for icebreaking operations. As shown in Table 1, the social marginal cost is EUR 6476 for a typical assistance operation and EUR 5304 for each assisted ship. The same cost is EUR 907 per running hour for the icebreakers and EUR 1990 per assisted hour. Each sailed nautical mile costs society another EUR 141 and each assisted nautical mile EUR 234.

Despite the significant costs, icebreaking in Sweden is free of charge for the shipper. These costs can be compared with the fee for pilotage to the port of Luleå in the Bay of Bothnia. A small ship with a gross tonnage (GT) of 2000 would pay EUR 1020 and a larger ship with a GT of 10,000 would pay EUR 1896 for the same 2-h pilotage in 2017. If ships had to pay for the social marginal costs that arise because of icebreaking, each assistance operation would cost three to five times more than the cited pilotage example. That would still not cover any of the icebreakers' fixed costs for capital and labour.

This study shows that previous studies based on average variable costs are inaccurate, since there is a statistically significant fixed cost related to icebreaking operations in addition to the costs that are fixed regardless of operations. The costs previously viewed as variable include a fixed part, so the average variable cost overestimates the marginal cost of icebreaking. Icebreakers spend considerable time standing by in the ice or sailing without assisting ships, consuming fuel without being directly engaged in assistance operations. The social marginal cost used in this study is only one third of the cost estimated by Vierth (2016) using the same value of external effects and including the same cost components.

This study also finds that the social marginal cost of icebreaking is not related to winter severity, and a very mild winter may even result in a higher marginal cost. The total cost is of course higher in severe winters because more ships are assisted, but the marginal cost per assistance operation or assisted ship is not, because operations can be more difficult during winters with smaller ice extents and ships are more often assisted together in convoys during severe winters.

\subsection{Policy implications and limitations}

Providing icebreaking services for free despite the high social marginal costs, as found here, causes non-optimal allocation of resources. A price equal to the social marginal cost would create incentives for shippers to consider other, more efficient alternatives than using sea transportation that requires icebreaking in winter. Any deviation from such pricing must be motivated by positive external effects or political concerns about the economy in the regions adjacent to the coasts served by state icebreaking. To maximise social welfare, only such shipping should be conducted when the benefits exceed the social marginal cost.

The policy in Sweden is that each means of transportation should pay its social marginal costs (see note 2). This means that external costs should ideally be internalised in the decision-making process of the transport users, either directly through regulations or indirectly through market-based instruments, such as taxes (Korzhenevych et al. 
2014). According to Transport Analysis (2019), the external costs of shipping in Swedish waters are on average $120 \%$ internalised, meaning that the shipping industry pays more in taxes and fees than the total cost of its external effects. In comparison, the external costs of road freight by heavy vehicles are 50-80\% internalised, meaning that the cost of the external effects of such road freight exceeds the taxes and fees paid by the sector. At the same time, the Swedish government (2018) has presented a national freight transport strategy for efficient, high-capacity and sustainable freight transport, one target of which is to promote the shifting of freight transport from road to rail and ship. Considering this strategy and the fact that the external costs of shipping are more than fully internalised, it may appear contradictory to propose a fee equal to the marginal cost of icebreaking services. Free icebreaking could be regarded as a means to shift transportation from road to sea to save the environment.

However, applying efficient pricing for icebreaking could be done without increasing the total amount of taxes and fees paid by the shipping sector. One way to achieve this would be to reduce the fairway fees by the same amount as the revenues from fees for icebreaking services. This would incentivize shippers to plan their operations and sail only when the benefits exceed the social marginal cost. The total burden on the shipping industry would be constant, eliminating the risk of shifting freight from sea to road.

Applying efficient pricing for icebreaking would not be simple in reality. Different pricing schemes could incentivize opportunistic behaviour among shippers, reducing the theoretically achievable efficiency. Above, six dimensions of marginal costs were analysed: per assistance operation, per assisted ship, per running hour, per assisted hour, per nautical mile and per assisted nautical mile. All are average social marginal costs over 14 years and do not reflect the actual short-term marginal cost of a specific assistance operation, which can vary substantially depending on the ice situation, location, ship characteristics, etc., and would moreover not be known in advance. Applying a price based on the average marginal cost could deter or stimulate the inefficient use of icebreaker assistance depending on whether the average marginal cost is higher or lower than the actual marginal cost of the specific assistance operation. At best, it may serve to guide shippers in planning whether to use transportation by ship or other alternatives in the winter.

A price equal to the social marginal cost per assisted hour or per assisted distance would reflect the costs of the resources consumed by the icebreaker for the actual assistance. The disadvantage of such pricing is that the cost would not be known to the shipper in advance, as it is difficult to determine beforehand how long the assistance would be needed. It would create an incentive to sail as long as possible without icebreaker assistance, which could put the ship farther away from the icebreaker when assistance is finally needed, hinder the creation of convoys or even place the ship in a more dangerous position.

A fixed price equal to the social marginal cost per assisted ship, regardless of time or distance, could be published in advance, making it possible for shippers to calculate the total cost of shipping to ports with ice. However, as this fixed price is an average of the costs of longer and shorter assistance operations, it may create disincentives for assistance use when only a short-assisted distance is expected, and it would not give incentives to create convoys. It would cross-subsidize assistance operations at ports located in northernmost Sweden, and adverse selection might occur as a result. 
A price per assistance operation, regardless of whether one or more ships are assisted at the same time, would give incentives to create convoys, if the assisted ships in a convoy shared the cost, but could provide incentives to free ride and cause problems of apportioning the costs among the ships. The price would not be known in advance, as it depends on how many ships participate in the assistance operation, and it has the same disadvantages concerning the different lengths of the assistance operations as does a price per assisted ship.

No price model is problem free, but it can be concluded that a price equal to the social marginal cost per assisted hour would create the best incentives, considering the advantages and disadvantages of the different models. It would be preferable to a distance-based price, as it would reflect the current ice situation. This is equivalent to the principle of the pilotage fee, which is also time based, making the shipper, not the service provider, take the risk or reap the benefits if a certain distance takes a longer or shorter time than expected. It would also benefit ships better equipped for sailing in ice. The problems arising from this, or any selected price model, might be mitigated by stricter regulation than today, stipulating the conditions for receiving assistance from state icebreakers.

Even if ships paid the social marginal cost, a large part of the total costs would still not be covered. The fixed capital and manning costs for icebreakers are substantial. On average over the studied period, 16-23\% of the total icebreaking costs to the Swedish Maritime Administration would be covered by social marginal cost pricing. Whether the remainder should be covered by the fairway fees paid by all ships destined to any Swedish port year round, as is the case today, or by tax money from the state is a political question. An alternative proposed by Andersson (2008) would be a two-part tariff combining a price equalling the social marginal cost with a fixed fee for ships entering ports in areas where and when the maritime authorities have issued ice restrictions. That could be regarded as an "entrance fee" for the right to obtain icebreaker assistance if it becomes necessary for the ship to reach its port.

Despite the discussed practical problems with implementing different price models, considering the large costs to society of icebreaking, a price model based on assisted time at least partly covering the costs could be implemented. As both the Swedish and Finnish Maritime Administrations already charge arriving ships a fairway fee, the price for using icebreaking services could be added to this fee without any significant transaction costs. Modern technology onboard the icebreakers could easily record the time that each vessel is assisted.

\subsection{Further research areas}

This study has highlighted the costs of providing icebreaking services in Sweden. In addition to its high fixed costs, icebreaking also has substantial social marginal costs that are at least as high as those of, for example, pilotage services. The present findings could be applied in other areas with ice in winter, serving as a basis for the design of efficient supply, pricing and financing of icebreaking services in the future in areas with ice in winter. More empirical research into icebreaking costs in other countries including studies involving more years, and more in-depth studies of the factors determining the costs and impacts of other external effects, such as waiting times for ships, would improve our knowledge of the cost structure of icebreaking. If a price model, as 
suggested above, is implemented, it would also be important to evaluate its effects on the demand for and efficiency of the icebreaking services.

Acknowledgements Open access funding provided by Linköping University.

Open Access This article is licensed under a Creative Commons Attribution 4.0 International License, which permits use, sharing, adaptation, distribution and reproduction in any medium or format, as long as you give appropriate credit to the original author(s) and the source, provide a link to the Creative Commons licence, and indicate if changes were made. The images or other third party material in this article are included in the article's Creative Commons licence, unless indicated otherwise in a credit line to the material. If material is not included in the article's Creative Commons licence and your intended use is not permitted by statutory regulation or exceeds the permitted use, you will need to obtain permission directly from the copyright holder. To view a copy of this licence, visit http://creativecommons.org/licenses/by/4.0/.

\section{References}

Andersson P (2008) Teoretiska och praktiska perspektiv på lotsningens och isbrytningens organisation och prissättning. Appendix to the Government Inquiry on Pilotage, SOU 2008:53

Boström M, Österman C (2017) Improving operational safety during icebreaker operations. J Marit Aff 16(1): 73-88

Coase RH (1974) The lighthouse in economics. J Law Econ 17(2):357-376

Dalaklis D, Drewniak ML, Schröder-Hinrichs J-U (2018) Shipping operations support in the "high north": examining avaliability of icebreakers along the North Sea route. WMU J Marit Aff 17(2):129-147

Effiong JAL, Aligbe JO, Uzoho BU, Eze EU (2016) Cost structure of trawl fisheries in Nigeria. Int J Adv Acad Res 2(2) https://www.ijaar.org/articles/volume2-number2/Sciences-Technology/ijaar-st-v2n2-f16p2.pdf

Eriksson G, Gullne U, Lindvall J, Karvonen T, Saurama A, Göthe-Lundgren M, Mellin A, Lindberg G (2009) CATRIN (Cost Allocation of TRansport INfrastructure cost), Deliverable D 10, Allocation of infrastructure cost in the maritime sector. Funded by Sixth Framework Programme. VTI, Stockholm, march 2009

Government bill (2005) /06:160. Moderna transporter. https://data.riksdagen.se/fil/92962290-19C0-40A69CF1-70FCCDBEEBB5

Government Decision (2017) -02-09. NT2017/01023/TS https:/www.regeringen.se/49192f/contentassets/7c7 c21f027c24150aaaafcdcf5fe968d/uppdrag-att-fortsatta-att-utveckla-forskningen-om-trafikenssamhallsekonomiska-kostnader.pdf

Gritsenko D, Kiiski T (2015) A review of Russian ice-breaking tariff policy on the northern sea route 19912014. Polar Rec 52(2):144-158 March 2016

Haralambides HE, Verbeke A, Musso E, Benacchio M (2001) Port Financing and Pricing in the European Union; Theory, Politics and Reality. Int J Marit Econ 3(4):368-386 December 2001

Korzhenevych A, Dehnen N, Bröcker J, Holtkamp M, Meier H, Gibson G, Varma A Cox V (2014) Update of the handbook on external costs of transport. Ricardo-AEA (Report for the European Commission: DG MOVE)

Lyridis DV, Psaraftis HN, Ventikos N, Zacharioudakis P, Dilzas K (2005) Cost-benefit analysis for ship automation retrofit: the case of icebreaker Frej. Mar Technol 42(2):113-124 April 2005

Meersman H, Pauwels T, Van de Voorde E, Vanelslander T (2010) Applying SMC pricing in PPPs for the maritime sector. Research in transport. Economics 30(1):87-101

Melin A, Creutzer C (2014) SJÖSAM-Sjöfartens samhällsekonomiska marginalkostnader; En förstudie inom SAMKOST VTI rapport 804

Näringsdepartementet (2003) Nya farledsavgifter, Ds 2003:41

Nerhagen L (2016) Externa kostnader för luftföroreningar; Kunskapsläget avseende påverkan på ekosystemet i Sverige, betydelsen av var utsläppen sker samt kostnader för utsläpp från svensk sjöfart. VTI-notat 24 2016

Ordinance (2010) 186 with instruction for Traffic Analysis. https://www.riksdagen.se/sv/dokumentlagar/dokument/svensk-forfattningssamling/forordning-2010186-med-instruktion-for_sfs-2010-186 
Parsons J, Dinwoodie J, Roe M (2011) Northern opportunities: a strategic review of Canada's Arctic icebreaking services. Mar Policy 35(4):549-556 July 2011

SCB (2016a) Importprisindex (IMPI), Rå petrolium. http://www.statistikdatabasen.scb. se/pxweb/sv/ssd/START_PR_PR0301_PR0301E/IMPIAr07/table/tableViewLayout1/?rxid=19b37c2 f-351b-46ba-afa2-f6f7f99095f1

SCB (2016b) Konsumentprisindex (KPI), Transporttjänster. http://www.statistikdatabasen.scb. se/pxweb/sv/ssd/START_PR_PR0101__PR0101A/KPICOI80Ar/table/tableViewLayout1/?rxid=19 b37c2f-351b-46ba-afa2-f6f7f99095f1

Somanathan S, Flynn PC, Szymanski JK (2007) Feasibility of a Sea Route through the Canadian Arctic. Marit Econ Logist 9(4):324-334 December 2007

Swedish Government (2018) Efficient, high-capacity and sustainable freight transport - a national freight transport strategy. https:/www.government.se/articles/2018/10/efficient-high-capacity-and-sustainablefreight-transport\%2D\%2Da-national-freight-transport-strategy/

Swedish Maritime Administration (2001) A summary of the ice season and icebreaking activities 2000/2001

Swedish Maritime Administration (2002) A summary of the ice season and icebreaking activities 2001/2002

Swedish Maritime Administration (2003) A summary of the ice season and icebreaking activities 2002/2003

Swedish Maritime Administration (2004) A summary of the ice season and icebreaking activities 2003/2004

Swedish Maritime Administration (2005) A summary of the ice season and icebreaking activities 2004/2005

Swedish Maritime Administration (2006) A summary of the ice season and icebreaking activities 2005/2006

Swedish Maritime Administration (2007). A summary of the ice season and icebreaking activities 2006/2007

Swedish Maritime Administration (2008) A summary of the ice season and icebreaking activities 2007/2008

Swedish Maritime Administration (2009) A summary of the ice season and icebreaking activities 2008/2009

Swedish Maritime Administration (2010) A summary of the ice season and icebreaking activities 2009/2010

Swedish Maritime Administration (2011) A summary of the ice season and icebreaking activities 2010/2011

Swedish Maritime Administration (2012) A summary of the ice season and icebreaking activities 2011/2012

Swedish Maritime Administration (2013) A summary of the ice season and icebreaking activities 2012/2013

Swedish Maritime Administration (2014) A summary of the ice season and icebreaking activities 2013/2014

Swedish Maritime Administration (2015) A summary of the ice season and icebreaking activities 2014/2015

Swedish Maritime Administration (2016) A summary of the ice season and icebreaking activities 2015/2016

Swedish Maritime Administration Annual Report (2017). http://www.sjofartsverket.se.

Swedish Maritime Administration (2019a) http://www.sjofartsverket.se/sv/Sjofart/Taxor-och-avgifter/Dennya-avgiftsmodellen/

Swedish Maritime Administration (2019b). http://www.sjofartsverket.se/sv/Sjofart/Isbrytning/Vintrarnassvarighetsgrad/

Swedish Meteorological and Hydrological Institute (2017) Charts of Maximum Ice Extension Since 1980 http://www.smhi.se/klimatdata/oceanografi/havsis

Swedish Riksbank (2017). http://www.riksbank.se.

Swedish Transport Administration (2016) Guidelines, ASEK. http://www.trafikverket.se/contentassets/4b1 c1005597d47bda386d81dd3444b24/11_luftfororeningar_a60_160906.pdf

Swedish Transport Agency (2015) Sveriges skeppslista 2015

Tchang GS (2019) The impact of ship size on ports' nautical costs. Maritime Policy \& Management. Published online 17 Sep 2019. https://doi.org/10.1080/03088839.2019.1657972

Transport Analysis (2017) Isbrytningens samhällsekonomiska marginalkostnad. PM 2017:4

Transport Analysis (2019) Transportsektorns samhällsekonomiska kostnader. Rapport 2019:4

Vierth I (2016) Sjöfartens policyrelevanta samhällsekonomiska marginalkostnader. VTI rapport 908

Vilmsmeier G (2016) International maritime transport costs. Market structures and network configurations. Routledge, London. https://doi.org/10.4324/9781315589442

Vilmsmeier G, Martinez-Zarzoso I (2010) Determinants of maritime transport costs — a panel data analysis for Latin American Trade. Transp Plan Technol 33:1. https://doi.org/10.1080/03081060903429447

VTI (2018) Organization of pilot and icebreaking in the Nordic countries and update of the external costs of sea transports in Sweden. VTI report 988A

Publisher's note Springer Nature remains neutral with regard to jurisdictional claims in published maps and institutional affiliations. 